\title{
Pre-Hispanic Distillation? A Biomolecular Archaeological Investigation
}

\author{
Patrick E McGovern*, Fabian H Toro, Gretchen R Hall, Theodore Davidson, Katharine Prokop Prigge, \\ George Preti, W Christian Petersen and Mike Szelewski \\ University of Pennsylvania Museum of Archaeology and Anthropology, USA
}

*Corresponding author: Patrick E Mc Govern, Biomolecular Archaeology Project, University of Pennsylvania Museum of Archaeology and Anthropology, Philadelphia, PA 19104, USA.

\author{
Received Date: February 15, 2019
}

Published Date: March 11, 2019

\begin{abstract}
Multiple, highly sensitive chemical techniques were used to analyze ancient pottery vessels from an excavated cemetery in Colima, west-central Mexico, dated to the Capacha phase (ca. 1500-1000 B.C). A double-chambered jar type, together with bowl and miniature cup types, are hypothesized to have been used as a pre-Hispanic distillation still. The results from the ancient vessels were compared to those from modern replica jars of the same types in which agave had been successfully distilled to a high-alcoholic beverage. Chemical biomarkers of agave in the modern replicas were absent from the ancient vessels, as were compounds of other native natural products of the region (e.g., maize, hog plum, prickly pear, etc.). Archaeological and archaeobotanical considerations, while suggestive, also provided no definitive evidence for a pre-Hispanic distillation hypothesis. Our study is placed within a broader ancient context of how this important technology for medicines, aromatics, metal purification, and alcoholic beverages, developed in east Asia and the Middle East, later to be adopted in Europe and brought to the New World. While an independent invention of a distillation apparatus in Mexico is yet to be proved, our goal is to stimulate further research and discussion, possibly leading to more compelling evidence.
\end{abstract}

Keywords: Biomolecular archaeology; Distillation; Pre-Hispanic Mexico; Agave; Fermentation; Archaeobotany; Pulque; Mezcal; History of science and technology; FT-IR; GC-MS; SPME

\section{Introduction}

Joseph Needham (1980:109-110, figure 1485b) first proposed that native Americans in the west-central highlands of Mexico as early as 1500 B.C. were not only fermenting Agave spp. to make beverages but were distilling them into "spirits." Needham based his case on pottery jars, which were peculiarly shaped with lower and upper chambers (e.g., figure 1A), that had been excavated from burials in Colima and its vicinity (Kelly 1980). He asserted that “...if [these jars were] surmounted by a cooling bowl and provided with a little catch-cup inside, alcohol could certainly have been distilled in them."

This was a revolutionary idea, since it would be the earliest distillation technology yet discovered in the world, some 1500 years in advance of China and the Middle East and some 3000 years before the arrival of the Spanish and Filipinos in Mexico, with their European and Asian distillation stills, in the fifteenth-sixteenth centuries A.D. But was it true?

\section{An Experimental Archaeological Approach}

Needham's hypothesis that the Colima double-chambered jars were pre-Hispanic stills was put to the test by botanist Daniel Zizumbo-Villarreal and colleagues (2009a). Modern pottery replicas of the ancient double-chambered jars and a Capacha-period round-bottomed bowl-type (figure 1B) and miniature cup-type (e.g., figure 1C) were first made by a local potter from local clay.

Macario Partida, a producer of the traditional distilled beverage made from agave (mezcal) in the village of Zapotitlán, and his wife, Maria, carried out the distillation in the pottery replicas over an open fire by pouring fermented agave liquid with fiber into the lower chamber of each double-chambered jar, suspending a cup by agave fiber inside the upper chamber, and then placing the bowl over the jar's mouth and sealing it to the jar with clay.

Five distillations of one liter of agave ferment were done. Each liter was boiled over a two-hour period. By continually replenishing 
the bowl with cold water, the evaporated gases from the ferment were condensed as a liquid that dripped from the underside of the bowl into the suspended cup. At the end of each experiment, the bowl was removed, and the liquid collected from inside each cup. Based on four experiments, the cup liquids averaged $20.5 \%$ alcohol by volume, greatly exceeding the $2-8 \%$ of a naturally fermented agave beverage, such as traditional pulque.

This success in using replica vessels to make a distilled beverage with a relatively high alcoholic content, however, still begged the question: Were the ancient Capacha vessels indeed used as an ancient "distillation still," and if so, was agave being distilled? There is a long history of domesticated plants in this general region of Mexico (Flannery 1986; Byers 1967; Zizumbo-Villarreal et al. 2012). Agave is certainly very important, but other natural products--including high-sugar fruits (hog plum, prickly pear, and guava), cactus juice, mesquite pods, and/or honey-might also have been fermented and distilled. Corn or maize, which is usually fermented into corn beer or chicha, cannot be ruled out, especially since it was domesticated close by in the central Balsas River basin. The early Spanish chroniclers describe a host of different fermented beverages (Zizumbo-Villarreal et al. 2009a), and the tradition of mixing together many kinds of ingredients was common in the past (Bruman 2000) and is still popular today, especially in the pulque bars of Mexico City. Any one of these fermented beverages might have been distilled in the ancient jars.

\section{The Archaeological and Archaeobotanical Evidence for a Pre-Hispanic Still}

The Capacha period in Colima and Jalisco provinces is still very poorly documented and understood. Kelly's excavations (1980). were confined to several burials. Mountjoy's investigation (2012). of a large cemetery at El Pantano provides the largest corpus of pottery and other artifacts, belonging to the Capacha and the later El Pantano (ca. 1000-800 B.C.) periods. The unusually shaped and unique "double-chambered jars" (Spanish, bules), are wellrepresented. They can have one to three intercommunicating hollow tubes between the two chambers, viz., the so-called gourdshaped, bifid, and trifid types, respectively.

Significantly, no occupational or workshop remains of the period, which might shed light on distillation technology, have yet been located and uncovered. We can only surmise how individual pottery vessel types might have been used in everyday life. Special vessels might only have been intended for the afterlife.

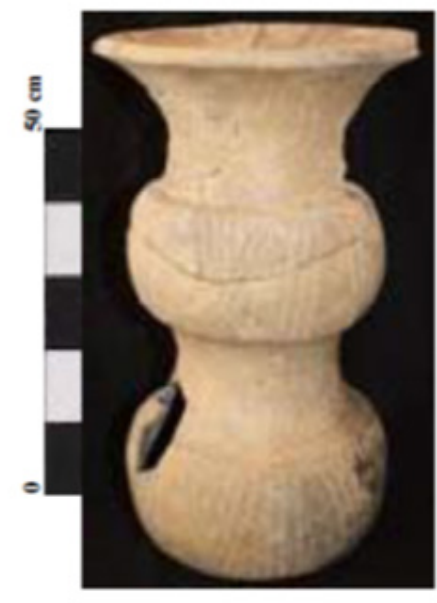

A
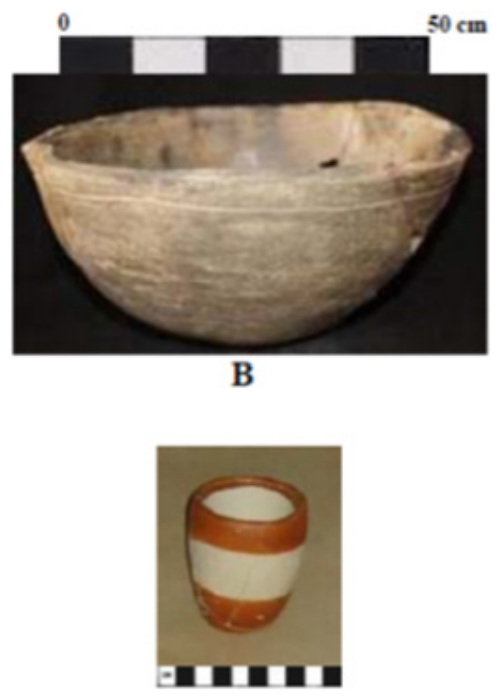

C

Figure 1: (A) Ancient gourd-type double-chambered jar, El Diezmo-Adonaí (Colima), grave 7, vessel no. 2, height 71cm; scale 1/7; (B) ancient round-bottomed bowl, El Diezmo-Adonaí (Colima), grave 9, vessel no. 7, diameter 60cm, scale 1/7; and (C) modern replica of miniature cup, sample no. 17 , height $6 \mathrm{~cm}$, scale $1 / 2$.

Most recently, two collaborators on the Zizumbo-Villarreal, et al. 2009a paper, archaeologists Laura Almendros López and Ramón López Montes of the INAH (National Institute of Anthropology and History), excavated undisturbed burials at the site of El DiezmoAdonaí in the city of Colima (Almendros López and López Montes 2011). The pottery in the tombs could be typologically dated to the Capacha phase (ca. 1500-1000 B.C.) of the Early Formative Period, although a radiocarbon determination gave a discrepant dating of ca. 150 B.C. The single inhumations at El Diezmo-Adonaí were accompanied by double-chambered jars exclusively of the gourd shape (Figure 1A).
The three vessel types (double-chambered jar, bowl, and miniature cup), comprising the hypothesized "distillation apparatus," have never been found together in situ, let alone with the vessels arranged as proposed. The closest approximation to such an apparatus is at El Diezmo-Adonaí where a double-chambered jar was found in the same burial (no. 9) in close proximity to a bowl that might once have covered the jar's mouth. But the bowl was not found in position on top of the double-chambered jar, so the two vessel types might well have served separate purposes.

No miniature cups or jars have yet been recovered from the El Diezmo-Adonaí tombs, let alone being inside double-chambered jar 
or providing information on how they might have been suspended inside the double-chambered jars.

Moreover, none of the El Diezmo-Adonaí double-chambered jars contained any maco-remains of agave or any other natural product in their interiors; flotation and sieving of soils was not done, and a micro botanical investigation, including pollen, phytoliths, and starch analyses, is yet to be carried out. Lower chambers would be expected to contain remnants of the fermented agave liquid and fiber. Perhaps, special precautions were taken in removing this material before burial, but it would have been difficult to remove every trace. Agave fibers, in particular, are especially strong and resistive to deterioration. But to date, no archaeobotanical remains of any plant have been recovered from the vessels or elsewhere in the tombs.

Round-bottomed bowls were also associated with doublechambered jars in the El Pantano cemetery, as were miniature cups. But, in no instance, were a jar, bowl, and cup found together in the same burial or in positions that indicated they were once part of a single installation.

Only one instance of a miniature vessel inside a larger jar is known from Parcela de Luis Salazar, northeast of Colima (Kelly 1980:46: figs. 12c and 14d). The jar was not double-chambered, but single-chambered of the so-called bean pot type. Zizumbo-Villarreal et al. 2009a (figure 7A) also illustrate a miniature jar, which is next to a trifid double-chambered jar on exhibit in the Regional Museum of Guadalajara, but it is not known if they were found together in the same archaeological context.

Two gourd-shaped double-chambered jars with gratings between the upper and lower chambers were found at El Pantano (Mountjoy 2012: fig. 53) and Quintero (Kelly 1980:55). They are very suggestive of a steaming, infusing, and/or distilling operation of some kind. Mountjoy is of the opinion that small bags of herbs were placed on the grate or suspended in bags from the mouths of jars, to prepare an herbal concoction. As similarly proposed for the pre-Hispanic still, water would have been boiled in the lower chamber with the vapor then rising up through the botanicals and then being condensed on the underside of a bowl of cold water covering the mouth of the upper chamber. By refluxing gaseous and liquid water repeatedly through the herbs, the liquid in the lower chamber would have become more and more concentrated with botanical compounds. This hypothesis fits with the way bean pots are still used today to cook and flush out cyanide poisons as gases from the beans.

Mountjoy also points to many small grinding stones in the tombs, which might have been used to crush herbs. He interprets the badly damaged rims of upper chambers as possibly due to pressure when the bags were inserted and removed, assuming that the hypothetical bags, which lack confirmatory archaeological evidence, were used. Yet, the crucial archaeobotanical evidence to determine what materials, if any, were being ground up and processed in the jars-whether by steaming, infusing, and/or distilling--is lacking thus far.

The double-chambered jars are not only unusually shaped, but they were often polished to an intense reddish color or were decorated with punctate, incised, or painted geometric designs. It is quite common for burial goods to be purely decorative, since they are intended as special gifts to the gods or ancestors in the after-life. Their practical use in this life or the next depends on other attributes. For example, if carbon deposits were observed on the exteriors of the lower chambers, but not on the outsides of the upper chambers, then that would imply that the lower chambers had been heated up over a fire, as posited by the pre-Hispanic hypothesis and as was observed for the modern replica jars. The El Diezmo-Adonaí jars show no sign of carbon on their exteriors, so it is unlikely that they were ever placed over a fire, unless any carbon were removed before the jars were deposited in the tombs. More study of vessels from this and other Capacha- and el-Pantanoperiod sites is needed.

In summary, considerable doubt exists as to whether such a distilling apparatus was ever used in antiquity, based on the available archaeological data and the lack of archaeobotanical evidence. A pre-Hispanic still with all the vessels arranged in the hypothesized arrangement is yet to be found.

\section{The Chemical Evidence for a Pre-Hispanic Still}

In the apparent absence of definitive archaeological and archaeobotanical evidence, our laboratory carried out chemical analyses of the ancient jars from El Diezmo-Adonaí in search of biomarkers (distinctive compounds) for the distillation of agave liquid ferment.

We pursued this initiative despite what might appear to be a poorly substantiated hypothesis, because of our prior experience in identifying organic residues of fermented beverages that were invisible to the eye. For example, most recently, we made a case for wine having been absorbed into terebinth tree resin on board the earliest Mediterranean shipwreck (McGovern and Hall 2015), and for grape juice having penetrated into the limestone matrix of the earliest winepress in France (McGovern et al. 2013b). Pottery, which was the focus of the Mexican study, lends itself well to chemical investigation, because organics, especially as liquids, are absorbed into its pores, whose ionic or polar properties can retain and preserve them for thousands of years (see McGovern and Hall 2015; Nigra et al. 2015).

By testing the pre-Hispanic distillation hypothesis, we also saw an opportunity to shed new light on one of the most important technological innovations by humans. Developing specific extraction and analytical techniques for this project held out the prospect of applying them in the analysis of other putative distillation apparatuses world-wide.

Some compounds are better for use as biomarkers than others. For example, terpenoids are relatively more water-insoluble and resistant to oxidation, particularly those lacking double bonds susceptible to epoxide formation (e.g., McGovern et al. 2013a). Lipids, on the other hand, can be more easily attacked and altered by hydrolytic and oxidative processes, making chemical and archaeological interpretation of the original natural products more difficult (Evershed 2012). 
We employed Fourier-transform infrared spectrometry (FTIR) and Gas Chromatography-Mass Spectrometry (GC-MS) in our analyses. GC-MS was also used to separate and analyze solvent extracts, as well as volatile organic compounds (VOCs) collected from samples using headspace Solid Phase Microextraction-GC-MS (SPME-GC-MS). For experimental procedures and protocols, see Appendix 1.

Our underlying assumption was that the same compounds, possibly chemically modified over time, might be present in both the modern replicas, which we knew had been used for experimentally distilling agave (Zizumbo-Villarreal et al. 2009a), and in the ancient pottery vessels. If that was indeed the case, then the pre-Hispanic hypothesis was highly probable; if not, then the hypothesis would be brought into question.

Laura Almendros Lopez provided ancient and modern replica pottery samples, as follows:

\section{Ancient samples}

i. Sherds of a gourd-type double-chambered jar (vessel no. 2; Figure $1 \mathrm{~A}$ ) in burial 7, including drilled samples from the interior of the lower chamber (Figure 2A) and from the interior and exterior of the upper chamber (Figures 2B and 2C, respectively). A soil sample (Figure 2D) came from the upper chamber of the same vessel.

ii. Sherds of a gourd-type double-chambered jar (vessel no. 6) in burial 7, including drilled samples from the interior of the lower chamber (Figure 6A) and from the interior and exterior of the upper chamber (Figures 6B and 6C, respectively).

iii. Scrapings (sample nos. 8A and 8B, respectively) from the interior base of the lower chamber and from the sidewall of the upper chamber of a gourd-type double-chambered jar (vessel no. 8) in burial 9. A soil sample (no. 8C) came from the upper chamber of the same jar.

iv. A sherd from a round-bottomed bowl (vessel no. 7; Figure 1B), also in burial 9, which provided a drilled sample from its exterior (Figure 7).

v. A sherd from the lower chamber of a gourd-type doublechambered jar (vessel no. 9) from an undefined burial context with human bone, which provided a drilled sample from its interior (no. 9).

\section{Modern samples}

i. A sherd of a gourd-type double-chambered jar (vessel no. 14), which provided a drilled sample from the lower chamber (no. 14).

ii. Sherds from a trifid-type double-chambered jar, which provided drilled samples from the interiors of the upper and lower chambers (nos. 15 and 16).

iii. A complete miniature cup (vessel no. 17; Figure 1C), which provided a drilled sample from its interior (sample no. 17). iv. A sherd from a round-bottomed bowl (vessel no. 18), which provided a drilled sample from its exterior (sample no. 18).

\section{Initial Observations, Extraction, and Sampling Targets}

The ancient and modern replica pottery sherds, soils, scraping, and vessel were first examined macroscopically and under low magnification for any potential residues, inclusions, and other characteristics of interest. No residues on the interiors of the ancient vessels were noted. The soil was very fine-grained and lacked inclusions.

For our analyses by FT-IR, GC-MS, and SPME-GC-MS, the interior surfaces of the sherds were ground down to a depth of $1-3 \mathrm{~mm}$ with a Dremel tungsten-carbide burr, avoiding any glue used in reconstruction. The outer surfaces of the upper chambers of two double-chambered jars (nos. 2 and 6) were also sampled for comparison with their interiors. The powdered samples are sometimes further ground down by an agate mortar and pestle, as needed. The soils and scraping were also reduced to powders by grinding. All the samples were extracted by our standard chloroform/methanol procedure by boiling 1-3 g of sample in glassware for 1 hour ( 2 times with fresh solvents for 30 minutes each), combining the solutions, and evaporating to dryness (see McGovern et al. 2013a; McGovern et al. 2013b; McGovern et al. 2009) The final extraction weights varied between 1-4mg.

The interiors of the lower chambers of the double-chambered jars were selected as the target areas for extraction and analyses by GC-MS, since the fermented agave liquid and fiber had been boiled in those chambers of the modern replica vessels and was similarly hypothesized to have been done for the ancient vessels. This analytical procedure is best able to detect a range of compounds (up to about 500 Daltons molecular weight), including terpenoids which are often characteristic of specific botanicals (below).

SPME-GC-MS can collect lower molecular-weight VOCs, which are lost during extraction using our standard GC-MS procedure (Appendix 1), but which comprise a large part of the evaporated vapors from the agave in the replicas. The latter would have risen into the jars' upper chambers, where they condensed on the bottom of a bowl of cold water. The liquid then collected on the bowl's exterior and dripped down into the miniature cup suspended below it. Based on these considerations, we targeted the upper chamber interiors of the double-chambered jars, the bowl exteriors, and the cup interiors for both modern and ancient vessels for SPME-GC-MS. Only a modern cup was available for analysis.

\section{FT-IR Results}

Initially, samples were screened for their organic content using our workhorse analytical technique, FT-IR (Appendix 1). The spectra (not shown) for both ancient and replica vessels did show good evidence for generic organics (e.g., absorptions by straightchain carbon-hydrogen stretching bonds at 2920 and $2850 \mathrm{~cm}^{-1}$ ) but were otherwise too non-specific to identify specific compounds. We therefore proceeded to GC-MS and SPME-GC-MS in hopes of 
obtaining more definitive information, especially for biomarkers, than by FT-IR.

\section{Analysis of Solvent Extracts by GC-MS, Results}

Modern replica pottery vessels. Figure 2 is the total ion chromatogram (TIC) generated by the GC-MS analysis of extracted compounds from the lower chamber of a modern replica doublechambered jar. It typifies the chemical results for two replica samples of this vessel type (nos. 14 and 16) in which we know that a fermented agave liquid with fiber was boiled. Both these vessels yielded essentially the same suite of compounds, viz., an even-numbered series of fatty acids (up to $\mathrm{C}_{26}$ for no. 14 and up to $C_{30}$ for no. 16), an even-numbered series of alcohols with behenic alcohol $\left(\mathrm{C}_{22}\right)$ dominant, and a series of plant and animal steroids and triterpenoids, denoted as I-N (see Figure 3). Glycerol (1,2,3-propane triol) is also found in both samples. The large peak for docos-9-enedioc acid $\left(\mathrm{C}_{22}\right)$ occurs in the solvent extraction blanks, which were run as controls, so it must be a contaminant; its origin is uncertain.

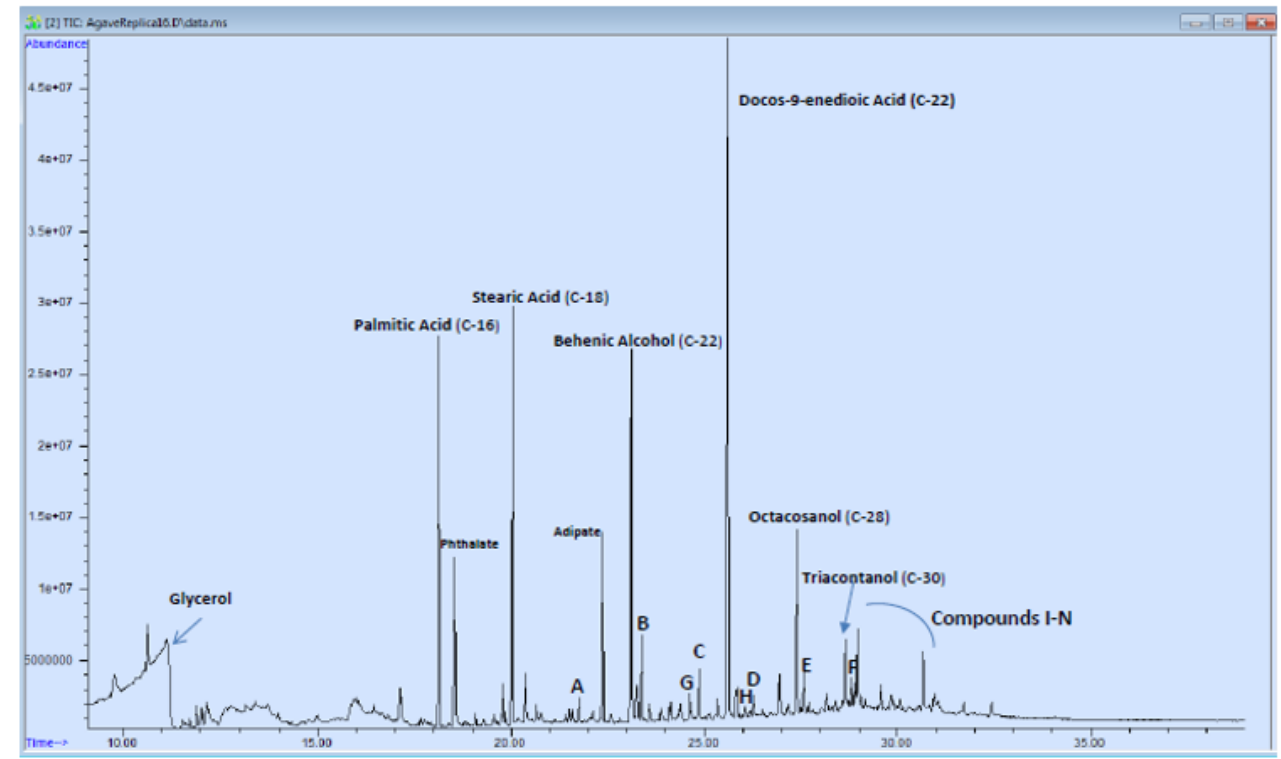

Figure 2: GC-MS chromatogram of lower chamber interior of modern replica of trifid-type double-chambered jar, El Diezmo-Adonaí (Colima), vessel no. 16. Compounds A-H are (A) $C_{20}$ fatty acid; (B) $C_{22}$ fatty acid; (C) $C_{24}$ fatty acid; (D) $C_{26}$ fatty acid; (E) $C_{28}$ fatty acid; (F) $C_{30}$ fatty acid; (G) $\mathrm{C}_{24}$ alcohol; and (H) $\mathrm{C}_{26}$ alcohol. Compounds I-N are shown in Figure 3. lon abundance of the total ion chromatogram (TIC) is shown on the $y$-axis (ordinate) and retention time on the $x$-axis (abscissa). e+ denotes an exponential.<smiles>CC(C)CCCC(C)C1CCC2C3CCC4CC(O)CCC4(C)C3CCC12C</smiles>

Cholesterol<smiles>CC1C2OC3(CCCCO3)C2C2CC3CCC4CC(O)CCC4(C)C3CCC12C</smiles>

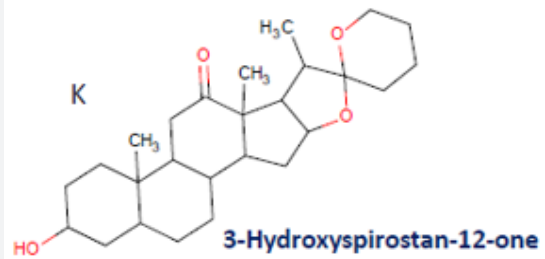<smiles>CCC(C)/C=C\C(C)C1CCC2C3CCC4CC(O)CCC4(C)C3CCC12C</smiles>

M<smiles>CCC(CCC(C)C1CCC2C3CCC4CC(O)CCC4(C)C3CCC12C)C(C)C</smiles>

Sitosterol

$\mathrm{N}$<smiles></smiles>

Stigmasta-3,5-dien-3-one

Figure 3: Plant and animal sterols and sapotenins denoted as I-N in Figure 2. 
Palmitic $\left(\mathrm{C}_{16}\right)$ and stearic $\left(\mathrm{C}_{18}\right)$ fatty acids are most prevalent in both jar samples, as they are in the solvent controls. Since they are widespread and abundant in microorganisms, plants and animals, they are not distinctive of agave. The combination of high molecular weight alcohols, fatty acids, and glycerol is typical of suberin, which is generic to plant cell walls, including agave. While consistent with the presence of agave, suberin is not a biomarker for this plant.

The steroidal and triterpenoid compounds I-N are of greatest interest as potential biomarkers of agave. They were identified, as were other compounds, by their excellent mass spectra matches to pure compounds in the NIST database (Appendix 1). Cholesterol, however, can be ruled out, because it occurs only in animal tissues; it is likely a contaminant due to human handling. Stigmasterol and its oxidized derivative (stigmasta-3,5-dien-3-one) and sitosterol are also generic to plants, so they are likewise not definitive for agave.

Triterpenoid compounds J (tigogenin) and $\mathrm{K}$ (3-hydroxyspirostan-12-one, also known as hecogenin) tell a different story. These two sapogenins (moieties of plant skin and tree bark saponins) have been reported in agave and a closely related genus, Furcraea (Simmons-Boyce and Tinto 2007).

Tigogenin is also found in potatoes and Douglas fir (Gandini, Neto, and Silvestre 2006). but these are unlikely candidates for processing in the double-chambered jars or coming in contact with the fermented agave liquid with fiber. According to our extensive search of the chemical literature (below), hecogenin occurs only in agave and Furcraea, and is not found in other plants of the Colima region. Both tigogenin and hecogenin would thus appear to be excellent biomarkers for the agave family.

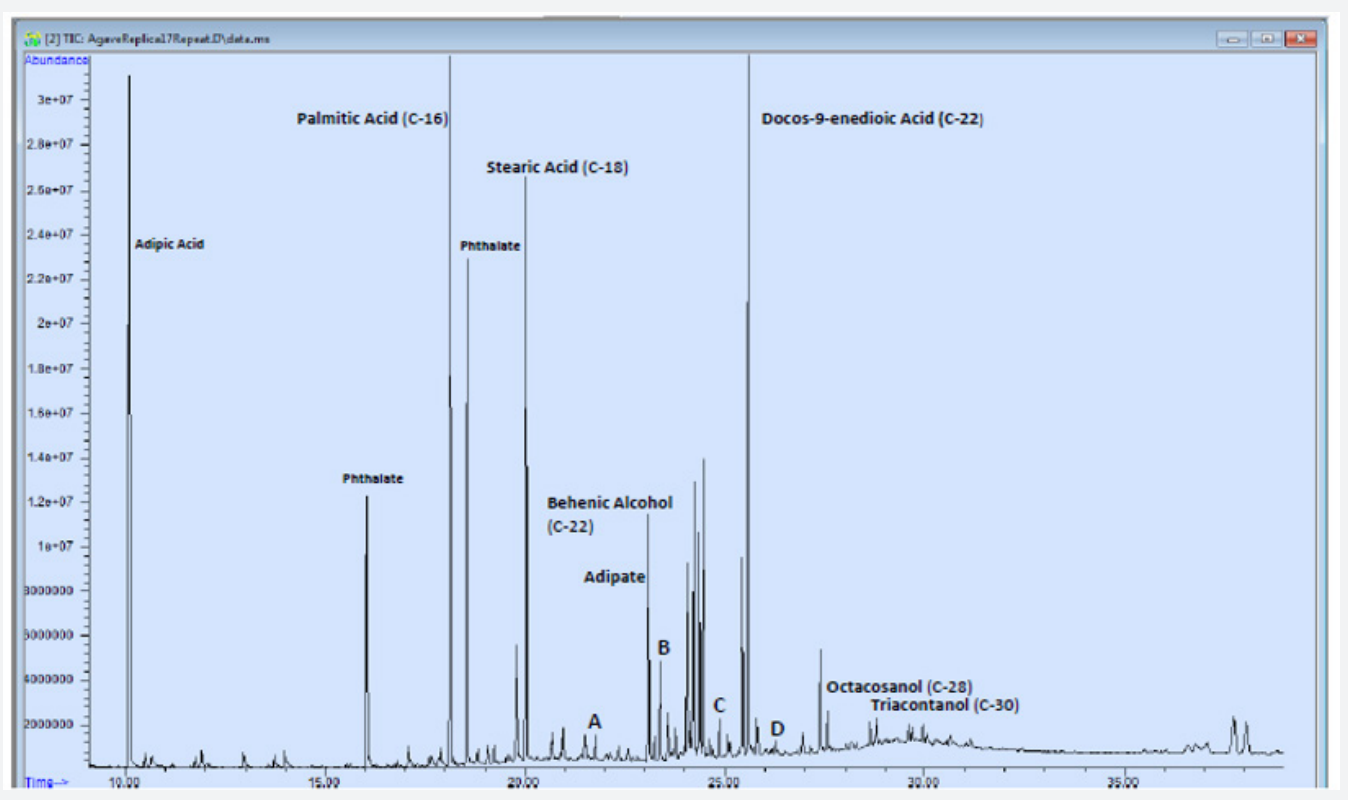

Figure 4: GC-MS chromatogram of modern replica of miniature cup interior (sample no. 17; Figure $1 C$ ). Compounds $A-D$ are $(A) C_{20}$ fatty acid; (B) $\mathrm{C}_{22}$ fatty acid; (C) $\mathrm{C}_{24}$ fatty acid; and (D) $\mathrm{C}_{26}$ fatty acid. Ion abundance of the total ion chromatogram (TIC) is shown on the ordinate and retention time on the abscissa. e+ denotes an exponential.

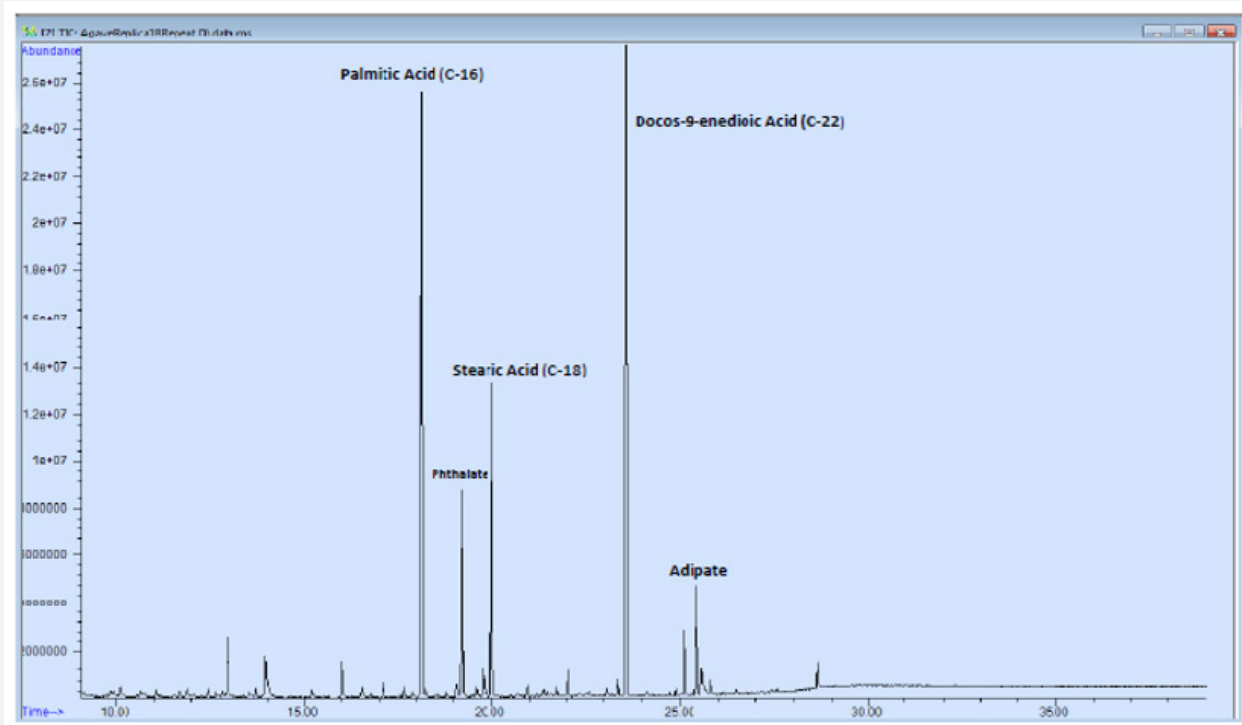

Figure 5: GC-MS chromatogram of modern replica of bowl exterior (sample no. 18). Ion abundance of the total ion chromatogram (TIC) is shown on the ordinate and retention time on the abscissa. e+ denotes an exponential. 
Figures 4 and 5 show the TICs for the corresponding modern replicas of a miniature cup and bowl used in the experiments by Zizumbo-Villarreal et al. (2009a). The chemical composition of the cup's pottery fabric (Figure 4) is very similar to that of the lower chamber of a double-chambered jar (Figure 2). The primary difference is the absence of higher molecular weight fatty acids and plant steroids and triterpenoids. We might expect this result, because the latter compounds have higher boiling points and are less likely to vaporize from boiling fermented agave liquid in the lower chamber and then re-condense in the upper chamber. The exterior bowl fabric is totally depleted in agave compounds (Figure 5), apart from palmitic and stearic acids. Its spectrum is dominated by contaminants: docos-9-enedioic acid and plasticizers (phthalates and adipates) found in the plastic bags in which the sherds were collected and stored. These results are again understandable, since the bowl was primarily exposed to gases and only transiently with liquid, which was not well absorbed into the pottery fabric.

Ancient pottery. Figure 6 typifies the GC-MS results we obtained for four samples (nos. 2A, 6A, 8A, and 9) --three drilled and one scraped--from the lower chambers of the ancient gourd-type double-chambered jars from the El Diezmo-Adonaí cemetery. The ever-present palmitic and stearic acids, several other low molecular weight fatty acids and alcohols, and traces of plant sterols probably derive from plants or microorganism activity in the soil. Modern contaminants included the ubiquitous docos-9-enedioic acid, and plasticizers (phthalates, amides, etc.). The exterior fabric from an ancient bowl (no. 7) produced a similar uninformative TIC. The biomarker triterpenoids for agave, hecogenin and tigogenin, were distinctly lacking in all the samples at retention times between 29 and 31 minutes where those compounds elute.

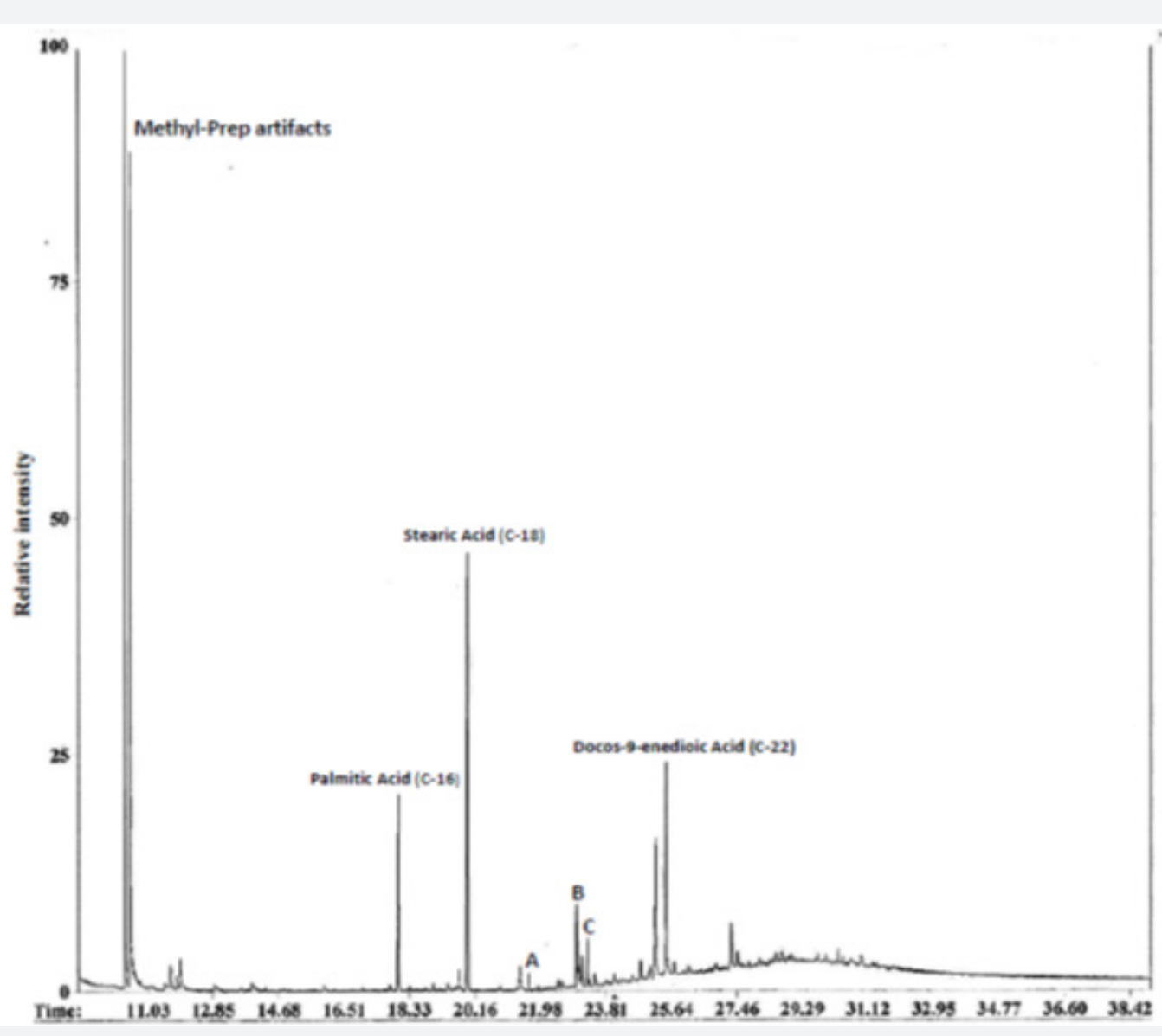

Figure 6: GC-MS chromatogram of lower chamber interior of ancient gourd-type double-chambered jar (sample no. 6A), El Diezmo-Adonaí (Colima), grave 7, vessel no. 6. Compounds A-C are (A) $C_{20}$ fatty acid; (B) $C_{22}$ alcohol; and (C) $C_{22}$ fatty acid. Note the absence of sterols and sapotenins at retention times between 29 and 31 minutes, as was observed for the modern replica jars (Figures 2 and 3 ). The large peaks at the start of the chromatogram are due to derivatization by Alltech II Me-Prep. The relative abundance of the total ion chromatograph is shown as a percentage on the ordinate.

\section{SPME-GC-MS Results}

We might have concluded our chemical investigation at this stage, since we had obtained negative GC-MS results for the lower chambers of two ancient double-chambered jars where we should have had biomarkers for agave or another native plant. But our sample size was small, and we could not rule out differential preservation over millennia. We decided to put the upper chambers of the jars to the test, as well.
As can be seen in Table 1, we carried out the collection of VOCs emanating from samples of the same replica bowl and miniature cup that were analyzed using solvent extraction and GC-MS. The sample of the double-chambered jar came from the interior upper chamber of a trifid-type jar replica (no. 15), which was used to distill agave liquid similarly to that carried out in the gourd-type (no. 14) and trifid-type (no. 16) jars, whose interior lower chambers were analyzed by solvent extraction and GC-MS. 
Table 1: SPME results for ancient and modern replica samples with literature citations.

\section{Table 1. SPME Results for Ancient and Modern Replica Samples with Literature Citations}

\begin{tabular}{|c|c|c|c|c|c|c|c|c|c|c|c|c|c|c|c|c|}
\hline \multirow{4}{*}{$\begin{array}{l}\text { Vessel type } \\
\text { Sample type } \\
\text { Sample no. }\end{array}$} & \multicolumn{12}{|c|}{ Ancient Pottery } & \multicolumn{3}{|c|}{ Modern Replica Pottery } & \multirow{4}{*}{ 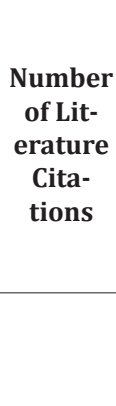 } \\
\hline & \multicolumn{4}{|c|}{ Gourd-type jar no. 2} & \multirow{2}{*}{\multicolumn{3}{|c|}{$\begin{array}{c}\begin{array}{c}\text { Gourd-type jar } \\
\text { no. } 6\end{array} \\
\text { Drilled Sample }\end{array}$}} & \multirow{3}{*}{\begin{tabular}{|c|}
$\begin{array}{c}\text { Bowl } \\
\text { no. } 7\end{array}$ \\
$\begin{array}{c}\text { Drilled } \\
\text { Sam- } \\
\text { ple }\end{array}$ \\
7 \\
\end{tabular}} & \multicolumn{3}{|c|}{ Gourd-type jar no.8: } & \multirow{3}{*}{$\begin{array}{c}\begin{array}{c}\text { Gourd- } \\
\text { type } \\
\text { no. } 9\end{array} \\
\begin{array}{c}\text { Drilled } \\
\text { Sample }\end{array} \\
9\end{array}$} & \multirow{3}{*}{$\begin{array}{c}\begin{array}{c}\text { Tri- } \\
\text { fid-type } \\
\text { jar }\end{array} \\
\begin{array}{c}\text { Drilled } \\
\text { Sample }\end{array} \\
15\end{array}$} & \multirow{3}{*}{$\begin{array}{c}\begin{array}{c}\text { Min- } \\
\text { iature } \\
\text { jar }\end{array} \\
\begin{array}{c}\text { Drilled } \\
\text { Sample }\end{array} \\
17 \\
\end{array}$} & \multirow{3}{*}{$\begin{array}{c}\text { Bowl } \\
\begin{array}{c}\text { Drilled } \\
\text { Sam- } \\
\text { ple }\end{array} \\
18\end{array}$} & \\
\hline & \multicolumn{3}{|c|}{ Drilled Sample } & \multirow{2}{*}{$\begin{array}{l}\text { Soil } \\
\text { 2D }\end{array}$} & & & & & \multicolumn{2}{|c|}{ Scraping } & \multirow{2}{*}{$\begin{array}{c}\text { Soil } \\
\text { 8B }\end{array}$} & & & & & \\
\hline & $\begin{array}{l}\text { 2B: } \\
\text { Run } 1\end{array}$ & $\begin{array}{c}\text { 2B: } \\
\text { Run } \\
2\end{array}$ & $2 \mathrm{C}$ & & $\begin{array}{c}\text { 6B: } \\
\text { Run } \\
1\end{array}$ & $\begin{array}{c}\text { 6B: } \\
\text { Run } \\
2\end{array}$ & $6 \mathrm{C}$ & & $\begin{array}{l}\text { 8A: } \\
\text { Run } 1\end{array}$ & $\begin{array}{c}\text { 8A: } \\
\text { Run } \\
2\end{array}$ & & & & & & \\
\hline \multicolumn{17}{|c|}{ Ketones } \\
\hline $\begin{array}{c}\text { 4-methyl } \\
\text { acetophenone }\end{array}$ & $\mathrm{x}$ & $\mathrm{X}$ & $\mathrm{X}$ & $\mathrm{X}$ & $\mathrm{X}$ & $\mathrm{x}$ & $\mathrm{X}$ & $\mathrm{X}$ & $\mathrm{X}$ & $\mathrm{x}$ & $\mathrm{X}$ & $\mathrm{x}$ & $\mathrm{x}$ & $\mathrm{x}$ & $\mathrm{X}$ & 1 \\
\hline acetophenone & $\mathrm{X}$ & $\mathrm{X}$ & $\mathrm{X}$ & $\mathrm{X}$ & $\mathrm{X}$ & $\mathrm{x}$ & $\mathrm{X}$ & $\mathrm{X}$ & $\mathrm{X}$ & $\mathrm{X}$ & $\mathrm{X}$ & $\mathrm{x}$ & $\mathrm{X}$ & $\mathrm{x}$ & $\mathrm{X}$ & 1 \\
\hline 2-nonanone & $\mathrm{X}$ & $\mathrm{X}$ & $\mathrm{X}$ & $\mathrm{X}$ & $\mathrm{X}$ & $\mathrm{x}$ & $\mathrm{X}$ & $\mathrm{X}$ & ND & $\mathrm{X}$ & $\mathrm{X}$ & $\mathrm{x}$ & $\mathrm{X}$ & ND & $\mathrm{X}$ & 1 \\
\hline 2-octanone & $\mathrm{X}$ & $\mathrm{X}$ & $\mathrm{X}$ & $\mathrm{X}$ & $\mathrm{X}$ & $\mathrm{X}$ & $\mathrm{X}$ & $\mathrm{X}$ & $\mathrm{X}$ & $\mathrm{X}$ & $\mathrm{x}$ & $\mathrm{x}$ & $\mathrm{X}$ & $\mathrm{X}$ & ND & 0 \\
\hline \multicolumn{17}{|c|}{ Aldehydes } \\
\hline 1-heptanal & $\mathrm{X}$ & $\mathrm{x}$ & ND & ND & ND & $\mathrm{X}$ & ND & $\mathrm{X}$ & ND & ND & ND & $\mathrm{x}$ & $\mathrm{X}$ & ND & ND & 2 \\
\hline octanal & $\mathrm{X}$ & $\mathrm{X}$ & $\mathrm{X}$ & $\mathrm{X}$ & $\mathrm{X}$ & $\mathrm{X}$ & $\mathrm{X}$ & $\mathrm{X}$ & $\mathrm{X}$ & $\mathrm{X}$ & $\mathrm{X}$ & $\mathrm{x}$ & $\mathrm{x}$ & $\mathrm{X}$ & $\mathrm{X}$ & 0 \\
\hline nonanal & $\mathrm{X}$ & $\mathrm{X}$ & $\mathrm{X}$ & $\mathrm{X}$ & $\mathrm{X}$ & $\mathrm{X}$ & $\mathrm{X}$ & $\mathrm{X}$ & ND & $\mathrm{X}$ & $\mathrm{X}$ & $\mathrm{X}$ & $\mathrm{x}$ & $\mathrm{X}$ & $\mathrm{X}$ & 0 \\
\hline furfural & $\mathrm{X}$ & $\mathrm{x}$ & $\mathrm{X}$ & $\mathrm{X}$ & $\mathrm{X}$ & & $\mathrm{X}$ & $\mathrm{X}$ & ND & ND & $\mathrm{x}$ & $\mathrm{x}$ & $\mathrm{X}$ & ND & ND & 5 \\
\hline benzaldehyde & $\mathrm{X}$ & $\mathrm{X}$ & $\mathrm{X}$ & $\mathrm{X}$ & $\mathrm{X}$ & $\mathrm{X}$ & $\mathrm{X}$ & $\mathrm{X}$ & ND & $\mathrm{X}$ & $\mathrm{X}$ & $\mathrm{X}$ & $\mathrm{X}$ & $\mathrm{X}$ & $\mathrm{X}$ & 3 \\
\hline \multicolumn{17}{|l|}{ Alcohols } \\
\hline octanol-l & $\mathrm{X}$ & $\mathrm{X}$ & $\mathrm{X}$ & $\mathrm{X}$ & $\mathrm{X}$ & $\mathrm{X}$ & $\mathrm{X}$ & $\mathrm{X}$ & ND & ND & $\mathrm{X}$ & $\mathrm{x}$ & $\mathrm{X}$ & $\mathrm{X}$ & ND & 4 \\
\hline nonanol-l & $\mathrm{X}$ & $\mathrm{X}$ & $\mathrm{X}$ & $\mathrm{X}$ & $\mathrm{X}$ & $\mathrm{X}$ & $\mathrm{X}$ & ND & ND & $\mathrm{X}$ & $\mathrm{X}$ & $\mathrm{x}$ & $\mathrm{x}$ & $\mathrm{X}$ & ND & 1 \\
\hline \multicolumn{17}{|c|}{ Terpenoids } \\
\hline camphor & $\mathrm{X}$ & $\mathrm{X}$ & $\mathrm{X}$ & $\mathrm{X}$ & $\mathrm{X}$ & $\mathrm{X}$ & $\mathrm{X}$ & $\mathrm{X}$ & $\mathrm{X}$ & $\mathrm{X}$ & $\mathrm{X}$ & $\mathrm{X}$ & $\mathrm{X}$ & $\mathrm{X}$ & $\mathrm{X}$ & 0 \\
\hline $\begin{array}{l}\text { camphene/ } \\
\text { limonene }\end{array}$ & ND & $\mathrm{X}$ & $\mathrm{X}$ & $\mathrm{X}$ & $\mathrm{X}$ & $\mathrm{X}$ & $\mathrm{X}$ & $\mathrm{X}$ & ND & ND & $\mathrm{X}$ & ND & ND & $\mathrm{X}$ & ND & 3 \\
\hline $\begin{array}{l}\text { alpha-terpin- } \\
\text { eol }\end{array}$ & $\mathrm{X}$ & $\mathrm{X}$ & $\mathrm{X}$ & $\mathrm{X}$ & $\mathrm{X}$ & $\mathrm{X}$ & $\mathrm{X}$ & $\mathrm{X}$ & $\mathrm{X}$ & $\mathrm{X}$ & $\mathrm{X}$ & $\mathrm{X}$ & $\mathrm{X}$ & $\mathrm{X}$ & ND & 4 \\
\hline $\mathrm{o} / \mathrm{p}$-cymene & $\mathrm{X}$ & $\mathrm{x}$ & $\mathrm{X}$ & $\mathrm{X}$ & $\mathrm{X}$ & $\mathrm{X}$ & $\mathrm{X}$ & $\mathrm{X}$ & $\mathrm{X}$ & $\mathrm{X}$ & $\mathrm{X}$ & $\mathrm{X}$ & $\mathrm{x}$ & ND & ND & 2 \\
\hline alpha-cedrol & $\mathrm{X}$ & $\mathrm{X}$ & $\mathrm{X}$ & ND & $\mathrm{X}$ & $\mathrm{X}$ & $\mathrm{X}$ & $\mathrm{X}$ & $\mathrm{X}$ & $\mathrm{X}$ & ND & ND & ND & ND & ND & 0 \\
\hline menthol & $\mathrm{X}$ & $\mathrm{X}$ & $\mathrm{X}$ & $\mathrm{X}$ & $\mathrm{X}$ & $\mathrm{X}$ & $\mathrm{X}$ & $\mathrm{X}$ & ND & ND & $\mathrm{X}$ & $\mathrm{X}$ & $\mathrm{X}$ & $\mathrm{X}$ & $\mathrm{X}$ & 0 \\
\hline borneol & $\mathrm{X}$ & $\mathrm{X}$ & ND & $\mathrm{X}$ & $\mathrm{X}$ & $\mathrm{X}$ & $\mathrm{X}$ & $\mathrm{X}$ & ND & ND & ND & $\mathrm{X}$ & $\mathrm{X}$ & $\mathrm{X}$ & $\mathrm{X}$ & 0 \\
\hline
\end{tabular}

As a double-check on reproducibility of data, we ran two separate samples of three of the jars (Figures $2 \mathrm{~B}, 6 \mathrm{~B}$, and $8 \mathrm{~A}$ ). The surface scraping of the interior of jar no. 8 , which contained less pottery fabric, predictably yielded fewer compounds.

We also ran samples from the exterior upper chambers of two jars (sample nos. 2C and 6C), as well as soil samples from the interiors of the upper chambers of two jars (sample nos. 2D and 8B), to check for the presence or absence of the same compounds in three different contexts (interior fabric, exterior fabric, and soil).

Figure 7 shows the TIC for the compounds detected in the upper chamber of an ancient gourd-type double-chambered jar (Figure 2A) in grave 7 of the El Diezmo-Adonaí (Colima) cemetery. This TIC which is typical of all the SPME collections and analyses-whether soil, interior pottery fabric, or exterior pottery fabric- -is dominated by 2-ethylhexanol (peak F), a modern plasticizerderived contaminant. By contrast, nearly every other peak is very small. The triterpenoids peaks are so minute-mere blips on the baseline-that they cannot be marked on the chromatogram. The identification of the compounds is assured by multiple runs, stringent controls, and the use of two independent mass spectral databases (see Appendix 1).

Most of the compounds in Table 1 are unlikely to be due to agave, because they are rarely or never cited in the available scientific literature (Appendix 2), as indicated in the right-hand column of the table. Menthol, for example, which is never cited in the literature, is often a constituent of moisturizers and other personal care products and could have been introduced by human handling in the field or laboratory if gloves were not worn. Other 
compounds are likely contaminants, because they were present in the water blanks, viz., nonanal, decanol, dodecanol, and possibly benzaldehyde (compare Figure 7). Phthalates are well-known plasticizers.

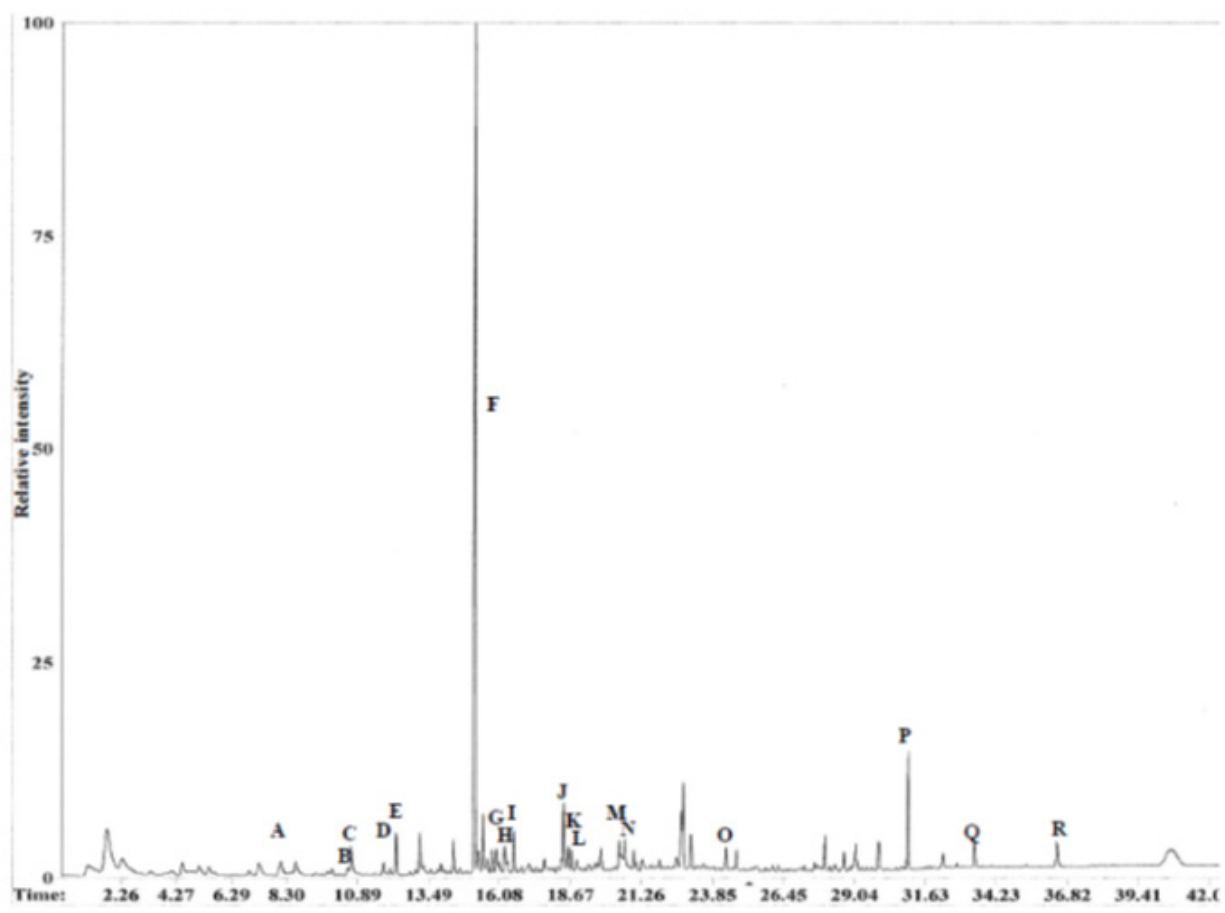

Figure 7: SPME GC-MS chromatogram of upper chamber interior of ancient gourd-type double-chambered jar (Figure 2A, El Diezmo-Adonaí (Colima), grave 7, vessel no. 2). Compounds A-Q are (A) heptanal; (B) octanone; (C) octanal; (D) nonanone; (E) nonanal; (F) 2-ethyl hexanol; (G) camphor; (H) benzaldehyde; (I) octanol; (J) menthol; (K) nonanol; (L) acetophenone; (M) fiber contaminant; (N) decanol; (O) dodecanol; $(P)$ diethyl phthalate; $(Q)$ diisobutyl phthalate; and $(R)$ dibutyl phthalate. Note that letters are placed above the peaks. Relative intensity $(\%)$ is shown on the ordinate and retention time on the $\mathrm{x}$-axis.

Seven compounds which are likely present in agave, based on their being cited two or more times in the literature, include heptanal, furfural, benzaldehyde, octanol, and the monoterpenoids camphene/limonene, alpha-terpineol, and o/p-cymene. None of these compounds, however, is a unique biomarker for agave, since they occur in other plants of the Colima region. Limonene is often problematic, since it is highly volatile and found in many cleaning solutions and personal care products.

We can partly assess the significance of these seven possible agave compounds by comparing the results for the soils and exterior pottery fabrics to those for the interior fabric. According to the pre-Hispanic distillation hypothesis, only the interior fabrics of the double-chambered jars' upper chambers would have come in direct contact with gases rising up from the boiling agave liquid and fiber in the lower chambers. The very fine-grained soils inside the vessels were not exposed to any vapors from distillation, because they accumulated in the empty jars post-burial. Likewise, the exterior fabrics of the upper chambers are unlikely to have been exposed to the gases, unless they passed through the sidewalls of the upper chambers. Their relatively well-fired, thick fabrics argued against this possibility.

The fact that all the putative agave compounds, with the exception of heptanal, uniformly show up in such diverse contexts-interior and exterior pottery fabrics of both replica and ancient pottery vessels, as well as later soils--implies that they have an origin other than the distillation of a fermented agave liquid. One might argue that the compounds are prevalent in the environments of both the ancient cemetery and the Colima museum and laboratory, but that seems unlikely given the different settings of lab and field.

A more likely explanation for the presence of the same suite of compounds in different contexts is that they were generated at very low levels by native air- and water-borne microorganisms that live in soils or can be absorbed and proliferate in pottery fabrics. Microscopic molds and bacteria, which are being increasingly studied by metabolomic, proteomic, genomic, and analytical chemical approaches (e.g., Yamada et al. 2015, and Tait et al. 2013), are now known to produce all the classes (hydrocarbons, ketones, aldehydes, alcohols, fatty and other organic acids, and terpenoids) and most of the specific compounds which were identified by our SPME analyses. Depending on the relative humidity and exposure to air-borne particulate matter, such as skin flakes and other organic debris, microbes can be expected to be nourished and proliferate.

\section{Discussion and Conclusion}

Needham's seemingly revolutionary hypothesis that the earliest distillation in the world began around 1500 B.C. in western Mexico has been tested and found wanting on all counts. The doublechambered jars, bowls, and miniature cups have not been found arranged in situ in the proposed arrangement as a "prehistoric agave still." The vessels are yet to be found in an occupational or industrial context. They occur only in tombs, and the decoration 
of the double-chambered jars suggests that they may be nonutilitarian and intended as burial goods. They show no carbon on the exteriors of their lower chambers, as would be expected if they had been used to boil a liquid over an open fire. Archaeobotanical remains of agave or other natural products of the Colima region are yet to be recovered inside the vessels or in their vicinity.

The experimental archaeological production of a more concentrated alcoholic drink by distilling an agave fermented liquid, while successful, is only suggestive that ancient native Americans did the same. Most telling, the lack of any firm chemical evidence, especially the total absence of the biomarkers tigogenin and hecogenin inside the lower chambers of the jars, seals the negative case against the hypothesis that agave or any other natural product of the region was distilled in the ancient vessels.

You can never prove a negative, however, especially in archaeology where we have a very small percentage of the original data set, with organic degradation and disappearance being an especially vexing problem, and there is always the possibility of new discoveries. Analyses of modern natural products are on-going, and we can expect additional insights from this line of investigation. These and other issues are addressed in more detail in a recent article, "Charting a Future Course for Organic Residue Analysis in Archaeology" (McGovern and Hall 2015).

But a negative case for a hypothesis need not be a death knell for further investigation. Indeed, this article is intended to spur further work on when and where ancient distillation began and was developed. A key point of our 2015 article is that a "working hypothesis" in biomolecular archaeology is continually redefining itself as more sensitive archaeological, chemical, botanical, and other techniques become available and are applied. As these methods improve and new data and hypotheses are generated, archaeologists, chemists, and other researchers should test previous results and cull out any "false positives." Any deduced consequences of such modified hypotheses then need to be tested further.

Other working hypotheses might explain the existing lack of archaeological, botanical, and chemical evidence for the vessels which comprise the "prehistoric agave still." For example, Mountjoy (2012) believes that steaming and infusing herbs with water is the most likely possibility. Like later bean pots, other natural products might also have been processed in this fashion. Distillation is only one of the possibilities for the vessels, and the least likely given the fact that the vessels go out of use ca. 800 B.C. and the next definite evidence for this process is the sixteenth century A.D., a gap of some 2300 years.

If distillation was not a native development in western Mexico in the Capacha period, did it only come into the region when the Spanish arrived some 3000 years later, bringing European technology with them to make distilled beverages in the New World, as they did elsewhere for rum? Because of the extensive trading networks of the Spanish in the sixteenth and seventeenth centuries A.D. across both the Atlantic and Pacific oceans, this is a real possibility that can't be ruled out; Valenzuela-Zapata et al. 2013 provide an excellent ethnohistorical and ethnographic overview (also see Hornsey 2016). In general, when Europeans arrived in the New World, they very soon began making fermented and distilled beverages.

Similarly, the Filipinos who were brought in by the Spanish in the late sixteenth c. A.D. to plant coconut trees, began making a distilled coconut beverage with equipment which is now standard in traditional mezcal operations in the Colima and Jalisco regions (Zizumbo-Villarreal and Colunga-GarcíaMarín 2008). By the seventeenth century, Spanish chroniclers report that these people were making coconut spirits from the resin or sap of the tree. Today, what is called coconut wine (lambanog) with up to $45 \%$ alcohol is still very popular and made by traditional methods in the Philippines using an Asian-type still.

Unfortunately, documentary evidence can be quite ambiguous and not definitive for the origins of distilled beverages in the Colima region. It should be noted, however, that before the Filipinos were brought in, one of the Spanish chroniclers as early as 1535 A.D. wrote that agave was being distilled by native peoples, assuming that to be the correct translation. Gonzalo Fernández de Oviedo wrote in 1535 A.D. that agave "...is cut from its stock, and the head or stump is cooked and made into a certain delicacy...and juice is extracted from the leaves by sweat through fire to distill [Spanish, destilarlo] it, and those people drink that liquor [Spanish, licor], because water they never see nor have, except for that of the sea..." (for translation and discussion, see Serra and Lazcano Arce 2010). This statement is nearly a century earlier than that of Domingo Lázaro de Arregui in 1619 A.D., which is often cited in support of the pre-Hispanic distillation hypothesis: "Mexcales [an agave variety] are quite similar to maguey and their roots and leaf bases are eaten roasted, and from the same, squeezing them thus roasted, they extract a must from which they obtain wine [Spanish, vino] by distillation [Spanish, alquitara], clearer than water and stronger than liquor [Spanish, aguardiente] and of that same taste" [for translation and discussion, see Zizumbo-Villarreal et al. 2009a, Zizumbo-Villarreal and Colunga-GarcíaMarín 2008). The last sentence is problematic, since aguardiente is now a generic term for any distilled beverage. Perhaps, the word referred to a lower alcoholic beverage at the time of de Arregui, perhaps even a naturally fermented pulque? However, these texts are to be translated and interpreted, they do not provide a sound basis from which to infer a native distillation industry before the Spanish arrived.

By contrast, ancient China has a long archaeological and documentary record of making fermented and distilled beverages using innovative techniques, reaching back to 7000 B.C. (McGovern et al. 2004). Although much controversy still swirls around how distillation began in east Asia and whether it was independently discovered there, this region has yielded the best and earliest archaeological evidence for distillation. An elaborate bronze vessel (Huang 2000:209-213, figs. 49 and 50), now in the Shanghai Museum and dated to the Eastern Han Dynasty from about 25 to 220 A.D., stands out. The main unit is a double-chambered vessel, like the Capacha jars, with a grating between the chambers, like jars from El Pantano and Quintero. Such a grating inside a vessel 
was used for Chinese cooking pots as early as the Neolithic period around 6000 B.C. A bowl with cold water, missing on the Shanghai still but present on comparable stills from several centuries later, was placed over the mouth of the vessel, such as is hypothesized for the Mexican Capacha jars.

For the Shanghai and similar stills, a double-rim of the upper vessel collected the condensate liquid as it condensed on the underside of the bowl and flowed downward. A projecting spout built into the double-rim dispensed the liquid. The stills were also furnished with a return spout for the condensate to flow back into the lower vessel where it could be repeatedly refluxed, and the volatile components of whatever natural products lay on the grating concentrated down. Such an apparatus would have been ideal for making medicines, perfumes, and distilled beverages of all kinds.

The same double-vessel and double-rim set-up, with only slight variations, has been used up until the present in China, sometimes on a massive scale (Huang 2000:208-231, figs. 47-48, table 24; also cf. figs. 51, 53-55, and 57). Another arrangement was to collect the condensate in a cup on the interior (Huang 2000: fig. 52:c), like the hypothetical Capacha still. In Mexico today, mezcal is generally collected on a condensate board, to which is attached a rolled agave leaf as an outside spout. This method likely originated with the Filipino Asian-type still compare (Huang 2000: fig. 52:d').

The earliest distillation apparatus known from the Middle East is distinctly different from the Asian-type still. Detailed drawings by the Egyptian alchemist Zosimos of Panopolis around 300 A.D. are believed to be accurate representations (Taylor 1945). They show a retort (a flask with a downward-pointed long neck) atop a small stove. Distillate vapors from boiling liquid inside the retort were directed through the tube-like neck to water-cooled flasks where they condensed into a liquid. The combined apparatus, which could be made in separate parts (e.g., lower jar with double-rim, upper jar, tube, and condensation jar), was known as an alembic. This apparatus was to become the Arab or Spanish still, which traveled to the New World (Needham et al. 1980:80-121).

Distillation technology might have been a much longer time coming to Europe, except that it was preserved and passed along to them by medieval Arab scholars. There are many words for "alcohol" in European languages, which derive from the Semitic root and phrase, al-kuhl, "the very dark," possibly referring to the distillation of manganese ore to make eye shadow in post-Pharaonic Egypt and later known as kohl.

The sophisticated arrangement of Zosimos' apparatus implies a lengthy developmental process for distillation technology in the Middle East. Some form of the technology appears to have been known as early as Aristotle, who wrote in the fourth century B.C. in his Meteorologica of salt water purification by evaporation, but he provided no details of how this was accomplished. Later writers spoke of condensing vapors from sea water, pitch (to make turpentine), and mercury (for separating the metal from the ore) on sheep fleeces and lids for references (see Taylor 1945).

No evidence for an alembic-like device, in situ and with all the parts in place, has yet been found in excavation; it is first documented during medieval times. Claims for such an apparatus have been made for ancient Mesopotamia (Levey 1955) and Pakistan (Rovesti 1980), dating as early as the late fourth millennium B.C. Arguments have also been advanced that spouted pottery jars at a second Pakistani site, dated to ca. 150 B.C. through the fourth century A.D., were coupled together for distillation. Long spouted jars, however, were quite common in antiquity, as were double-rims, especially for cooking pots. Both could have served other purposes than collecting a distillate, viz., to dispense a beverage ceremonially or to hold a lid in place.

It is noteworthy that comparable developments in distillation technology appear to have been occurring on both sides of Asia about the same time. Trade relations were well-attested during the Hellenistic, Roman, and Byzantine periods by sea and overland through central Asia, along the routes later called the Silk Road, so a cross-fertilization of ideas might have occurred. Each region, however, pursued the technology along different lines and devised their own apparatuses.

This brief overview of distillation history and archaeology helps put in perspective the pre-Hispanic distillation hypothesis in westcentral Mexico as early as ca. 1500 B.C. Pottery evidence from the Capacha and El Pantano periods, especially later double-chambered jars with interior gratings, suggests that a knowledge of steaming and/or infusing natural products existed, matching evidence from early China, and eventually could have led to an independent invention of a distillation apparatus there. Yet, to date, conclusive archaeological, archaeobotanical, and/or chemical evidence for the hypothesis is lacking, so that it must be judged unproven until new data are forthcoming.

\section{Acknowledgments}

Our biomolecular archaeological project was made possible by the INAH (National Institute of Anthropology and History) in Mexico. Above all, we thank Laura Almendros López at the Institute's office and museum in Colima where Patrick E. McGovern (PEM) examined the pottery and other artifacts from the El Diezmo-Adonaí cemetery. Laura explained what they had found in their excavations by a personal tour of the site. Laura prepared and packed the pottery and soil samples to be hand-carried by PEM back to the U.S., catalogued and documented them fully, and was the signatory to the INAH agreement. She advised on archaeological matters for the site and for ancient Mexico generally. She translated the abstract into Spanish. The data and interpretations presented in this paper, however, are strictly those of the co-authors.

Other INAH and Mexican colleagues made important contributions. Patricia Colunga-GarcíaMarín and her husband, Daniel Zizumbo-Villarreal, of the Unidad de Recursos Naturales of the Centro de Investigación Científica de Yucatán in Mérida (Yucatán) provided much-needed advice and answers to botanical queries. Fernando González-Zozaya of the Centro INAH Colima also contributed to the tour of the site and was helpful in other respects.

PEM's trip to Mexico was financed by David Suro Piñera, then president of the Tequila Interchange Project. 
Financial support for the analyses, equipment maintenance, and laboratory supplies was fully borne by the Biomolecular Archaeology Project of the Penn Museum and collaborating institutions, viz., the Scientific Research and Analysis Laboratory (SRAL) of the Winterthur Museum Conservation laboratory and the Monell Chemical Senses Center. A private donor generously provided additional supplies. Katharine (Prokop) Prigge was supported by NIH Training Grant \#2T32DC000014-32A1.

The six analytical chemists, who are co-authors on the paper, gave generously of their time and expertise in preparing the samples, extracting them, and carrying out the analyses. They included Gretchen H. Hall and Theodore Davidson at the Penn Museum, W. Christian Petersen and Mike Szelewski of Winterthur (GC-MS and FT-IR), and Katharine (Prokop) Prigge and George Preti of Monell (SPME-GC/MS).

Jason Eades at Monell assisted Fabian Toro, a University of Pennsylvania undergraduate in Chemical Engineering, in performing the SPME collections and subsequent GC-MS analyses of collected VOCs.

Other colleagues who advised on archaeological, textual, and scientific matters included Alexandr Gorokhovskiy, Dan Healan, Ian Hornsey, Pedro Jiménez, Victor Mair, Joseph Mountjoy, and Ana Valenzuela-Zapata.

\section{Conflict of Interest}

No conflict of interest.

\section{References}

1. Allchin Frank R (1979) India: The Ancient Home of Distillation? Man, new series 14(1): 55-63.

2. Almendros López Laura, Ramón López Montes (2011) Informe técnico parcial del rescate arqueológico en el predio parcela 18 Z-1 P1\} \backslash 1 \text { del } Ejido El Diezmo, Colima, Colima. Unpublished report on file at INAH (National Institute of Anthropology and History), Colima.

3. Arellano Melchor, Carlos Pelayo, Jesús Ramírez, Ingrid Rodriguez (2008) Characterization of Kinetic Parameters and the Formation of Volatile Compounds during the Tequila Fermentation by Wild Yeasts Isolated from Agave Juice. Journal of Industrial Microbiology and Biotechnology 35(8): 835-841.

4. Bonaduce Ilaria, Erika Ribechini, Fancesca Modugno, Maria Perla Colombini (2016) Analytical Approaches Based on Gas Chromatography Mass Spectrometry (GC/MS) to Study Organic Materials in Artworks and Archaeological Objects. Topics in Current Chemistry 374(1): 6.

5. Bruman Henry J (2000) Alcohol in Ancient Mexico. University of Utah, Salt Lake City.

6. Byers Douglas S (1967) The Prehistory of the Tehuacan Valley. Vol. 1: Environment and Subsistence. University of Texas, Austin.

7. Ceva-Antunes Patricia MN, Humberto Ribeiro Bizzo, Alberdan S Silva, OAC Antunes (2003) Analysis of Volatile Composition of Siriguela (Spondias purpurea L.) by Solid Phase Microextraction (SPME). LWTFood Science and Technology 39(4): 437-443.

8. Colunga García Marín Patricia, Daniel Zizumbo Villarreal (2007) Tequila and Other Agave Spirits from West-Central Mexico: Current Germplasm Diversity, Conservation and Origin. Biodiversity and Conservation 16: 1653-1667.
9. de Arregui, D. Lázaro (1946) Descripción de la Nueva Galicia. Publications of the School of Hispanic-American Studies of the University of Seville, 24 edited by François Chevalier. School of Hispanic-American Studies, Seville.

10. de León-Rodríguez, Antonio, Pilar Escalante Minakata, María I JiménezGarcía, Leandro G Ordoñez Acevedo, José L Flores Flores, et al. (2006) Characterization of Volatile Compounds of Mezcal, an Ethnic Alcoholic Beverage Obtained from Agave salmiana. Journal of Agricultural and Food Chemistry 54: 1337-1341.

11. de León-Rodríguez, Antonio, Pilar Escalante Minakata, María I JiménezGarcía, Leandro G Ordoñez Acevedo, José L Flores Flores (2008) Characterization of Volatile Compounds from Ethnic Agave Alcoholic Beverages by Gas Chromatography Mass Spectrometry. Food Technology and Biotechnology 46(4): 448-455.

12. de Sousa Galvao, Mércia, Narendra Narain, Maria do Socorro Porto dos Santos, Maria Lúcia Nunes (2010) Volatile Compounds in Umbu (Spondias tuberosa) Fruits during Maturation. Food Research International 44(7): 1919-1926.

13. Evershed Richard P (2012) Experimental Approaches to the Interpretation of Absorbed Organic Residues in Archaeological Ceramics. World Archaeology 40(1): 26-47.

14. Flannery Kent V (2009) Guila Naquitz: Archaic Foraging and Early Agriculture in Oaxaca, Mexico. Studies in Archaeology. Academic, Orlando Florida.

15. Gandini A, CP Neto, AJD Silvestre (2006) Suberin: A Promising Renewable Resource for Novel Macromolecular Materials. Progress in Polymer Science 31(10): 878-892.

16. Hornsey I (2016) Waiting for the Sunrise. Brewer and Distiller International 12(6): 36-44.

17. Huang HT (2000) Biology and Biological Technology, Part V: Fermentation, and Food Science = Science and Civilization in China, J. Needham (Edt.), Cambridge University, Cambridge, USA, Vol. 6.

18. Kelly Isabel T (1980) Ceramic Sequence in Colima: Capacha, an Early Phase. Anthropological Papers, University of Arizona, Tucson, pp. 37.

19. Levey Martin (1955) Evidence of Ancient Distillation Sublimation and Extraction in Mesopotamia. Centaurus 4(1): 23-33.

20. McGovern Patrick E, Gretchen R Hall (2015) Charting a Future Course for Organic Residue Analysis in Archaeology. Journal of Archaeological Method and Theory, 23: 592-622.

21. McGovern Patrick E, Gretchen R Hall, Armen Mirzoian (2013) A Biomolecular Archaeological Approach to "Nordic Grog." Danish Journal of Archaeology 2(2): 112-131

22. McGovern Patrick E, Donald L Glusker, Robert A Moreau, Alberto Nuñez, Elizabeth Simpson. (1999) A Funerary Feast Fit for King Midas. Nature 402: 863-864.

23. McGovern Patrick E, Benjamin P Luley, Nuria Rovira, Armen Mirzoian, Michael P Callahan (2013) The Beginning of Viniculture in France. The Proceedings of the National Academy of Sciences, USA 110(25): 1014710152.

24. McGovern Patrick E, Armen Mirzoian, Gretchen R Hall (2009) Ancient Egyptian Herbal Wines. The Proceedings of the National Academy of Sciences, USA 106(18): 7361-7366.

25. McGovern Patrick E, Juzhong Zhang, Jigen Tang, Zhiqing Zhang, Gretchen R Hall (2004) Fermented Beverages of Pre- and Proto-Historic China. The Proceedings of the National Academy of Sciences, USA 101(51): 17593-17598.

26. Molina Guerrero JA, JE Botello Álvarez, A Estrada Baltazar, JL Navarrete Bolaños, H Jiménez Islas (2007) Volatile compounds in Mezcal. Mexican Journal of Chemical Engineering 6: 41-50. 
27. Mountjoy Joseph B (2012) El Pantano: and other sites of the middle formative in the Mascota Valley, Jalisco. Secretary of Culture, Guadalajara

28. Needham Joseph (1980) Science and Civilisation in China. Vol. 5: Chemistry and Chemical Technology, Part 4: Spagyrical Discovery and Invention: Apparatus, Theories and Gifts. Cambridge University, Cambridge, USA.

29. Nevárez Martell, María Angélica, Córdova Gurrola, Olga Miriam (2011) Effect of Fermentation Temperature on Chemical Composition of Mescals Made from Agave duranguensis Juice with Different Native Yeast Genera. African Journal of Microbiology Research 5(22): 3669-3676.

30. Nigra Benjamin T, Kym F Faulland, Hans Barnard (2015) Analytical Chemistry in Archaeological Research. Analytical Chemistry 87(1): 3-18.

31. Peña Alvarez A, Laura Díaz, Alejandra Medina, Carmen Labastida, Santiago Capella, et al. (2004) Characterization of Three Agave Species by Gas Chromatography and Solid Phase Micro extraction Gas Chromatography Mass Spectrometry. Journal of Chromatography A 1027(1-2): 131-136.

32. Pino Jorge, Leanna Bent (2013) Odour active compounds in guava (Psidium guajava L. cv. Red Suprema). Journal of the Science of Food and Agriculture 93(12): 3114-3120.

33. Prado Jaramillo Norma, Mirna Estarrón Espinosa, Héctor B EscalonaBuendía, Sandra Teresita Martín del Campo (2015) Volatile Compounds Generation during Different Stages of the Tequila Production Process: A Preliminary Study. Lebensmittel Wissenschaft and Technology Food Science and Technology 61: 471-483.

34. Riffell Jeffrey A, Ruben Alarcón, Leif Abrell, Goggy Davidowitz, Judith L Bronstein (2008) Behavioral Consequences of Innate Preferences and Olfactory Learning In Hawkmoth Flower Interactions. The Proceedings of the National Academy of Sciences, USA 105(9): 3404-3409.

35. Rizwan Komal, Muhammad Zubair, Nasir Rasool, Muhammad Riaz, Muhammad Zia Ul Haq, Vincenzo de Feo (2012) Phytochemical and Biological Studies of Agave attenuata. International Journal of Molecular Science 13(5): 6440-6451.

36. Rovesti Paolo (1980) Alla scoperta del primo alambico del mundo: la distillazione ha cinque mila anni, Rivista italiana EPPOS 62(7): 342-345.

37. Serra MC, Lazcano Arce C (2010) The Drink Mescal: Its Origin and Ritual Uses. In Pre-Columbian Foodways: Interdisciplinary Approaches to Food, Culture and Markets in Ancient Mesoamerica. J. Staller and M. Carrasco (Eds.), Springer, New York, pp. 137-156.
38. Simmons Boyce, Joanne L, Winston F Tinto (2007) Steroidal Saponins and Sapogenins from the Agavaceae Family. Natural Product Communications 2(1): 99-114.

39. Tait Emma, John D Perry, Stephen P Stanforth, and John R. Dean (2013) Identification of Volatile Organic Compounds Produced by Bacteria Using HS SPME GC MS. Journal of Chromatographic Science 52(4): 363373.

40. Taylor F Sherwood (1945) The Evolution of the Still. Annals of Science 5(3): 185-202.

41. Valenzuela Zapata Ana G, Paul D Buell, María de la Paz Solano Pérez, Hyunhee Park (2013) "Huichol" Stills: A Century of Anthropology Technology Transfer and Innovation. Crossroads 8: 157-191.

42. Vera Guzmán A, Guzmán Gerónimo RI, López MG (2010) Major and Minor Compounds In A Mexican Spirit: Young Mezcal Coming from Two Agave Species. Czech. Journal of Food Science 28: 127-132.

43. Wright CR, WN Setzer (2014) Chemical Composition of Volatiles from Opuntia littoralis, Opuntia ficus indica, and Opuntia prolifera Growing on Catalina Island, California. Natural Product Research 28(3): 208-211.

44. Yamada Yuuki, Tomohisa Kuzuyama, Mamoru Komatsu, Kazuo Shinya, Satoshi Omura (2015) Terpene Synthases Are Widely Distributed in Bacteria. The Proceedings of the National Academy of Sciences, USA 112(3): 857-862.

45. Zizumbo Villarreal Daniel, Patricia Colunga GarcíaMarín (2008) Early Coconut Distillation and the Origins of Mezcal and Tequila Spirits in West Central Mexico. Genetic Resources and Crop Evolution 55: 493-510.

46. Zizumbo Villarreal Daniel, Fernando González Zozaya, Angeles Olay Barrientos, Laura Almendros López, Patricia Flores Pérez, et al. (2009) Distillation in Western Mesoamerica before European Contact. Economic Botany 63: 413-426.

47. Zizumbo Villarreal Daniel, Fernando González Zozaya, Angeles Olay Barrientos, Rafael Platas Ruíz, Mariza Cuevas Sagardí, et al. (2009) Archaeological Evidence of the Cultural Importance of Agave spp. in PreHispanic Colima. Economic Botany 63: 288-302.

48. Zizumbo Villarreal Daniel, Alondra Flores Silva, Patricia Colunga García Marín (2012) The Archaic Diet in Mesoamerica: Incentive for Milpa Development and Species Domestication. Economic Botany 66: 328-343. 